\section{ANALYSIS OF THE PRESENCE OF ORGANIC MATTER (ATP) IN MOBILE DEVICES OF HEALTHCARE WORKERS IN HOSPITALS}

\author{
Eunice Beatriz Martin Chaves' ${ }^{1}$, Mônica Beatriz Agnes ${ }^{1}$, \\ Loriane Rita Konkewicz ${ }^{2}$, Ana Lucia Kern Thomas ${ }^{3}$, \\ Jacqueline Jacques ${ }^{1}$, Maurício Nunes Madeira ${ }^{1}$
}

\begin{abstract}
We report the result of an awareness campaign about the importance of hand hygiene after using different devices used in assistance to patients, such as tablets, notebooks, mobile phones, identification cards, watches, cameras, showing the level of contamination found after detection of adenosine triphosphate (ATP) via bioluminescence, which enables a quantitative assessment ready and easy to implement. ATP molecules found in all living cells react with the enzyme complex to generate light and represent the presence of organic matter in such objects.
\end{abstract}

Hospital Infection Control Committee Hospital de Clínicas de Porto Alegre (HCPA). Porto Alegre, RS, Brasil.

3 Environmental and Sanitation Service, Hospital de Clínicas de Porto Alegre (HCPA). Porto Alegre, RS, Brasil.

Corresponding author: Eunice Beatriz Martin Chaves ebmchaves@hcpa.edu.br Hospital de Clínicas de Porto Alegre (HCPA)

Rua Ramiro Barcelos, 2350.

90035-903, Porto Alegre, RS, Brasil.
Keywords: Nosocomial infection; fomites; hand hygiene.

The mobile system created in the 1980's to provide better communication network and today's mobile phones, tablets, electronic organizers (PDAs) have become indispensable accessories of professional and social life. Mobile phones are also becoming an increasingly important means of communication between healthcare workers (HCWs) in hospitals where infections associated with some devices are prevalent, contributing significantly to the morbidity and mortality of patients ${ }^{1}$. It is estimated that one third of all hospital infections are preventable and are often caused by organisms acquired in hospital ${ }^{2}$. The hands of HCWs play an important role in the transmission of pathogens from mobile phones and other devices, which are rarely cleaned and are often used during or after the examination of patients, without proper hand washing after use. It has been reported that medical devices such as thermometers, stethoscopes, and non-medical devices including computer keyboards, faucets, ballpoint pens, files, books, and mobile phones play an important role in the transmission and spread of microorganisms ${ }^{3}$. It could function as a reservoir as well as a vehicle for the transmission of nosocomial infections ${ }^{4,5}$. The potential of mobile phones as vectors for hospital infection has been studied before ${ }^{6-9}$.

The objective of this study was to determine the presence of organic matter with contamination potential in some devices from health professionals during an awareness campaign about the importance of hand hygiene.

\section{METHOD}

This study was carried out during a campaign to raise the awareness of the importance of hand hygiene held in May 2015 during the different work shifts, covering all HCWs of the institution who consented to participate.

The cleanliness of different devices used by HCWs (mobile phones, tablets, notebooks, identification cards, watches, cameras) was assessed through the detection of adenosine triphosphate (ATP) via bioluminescence, which allows an immediate quantitative assessment of ATP molecules found in all living cells. These molecules react with the enzyme complex, generate light, and represent the presence of organic matter in such objects. The analysis was performed using a device called luminometer (figure 1) to measure the intensity of the light captured and expressed in relative light units (RLU). 


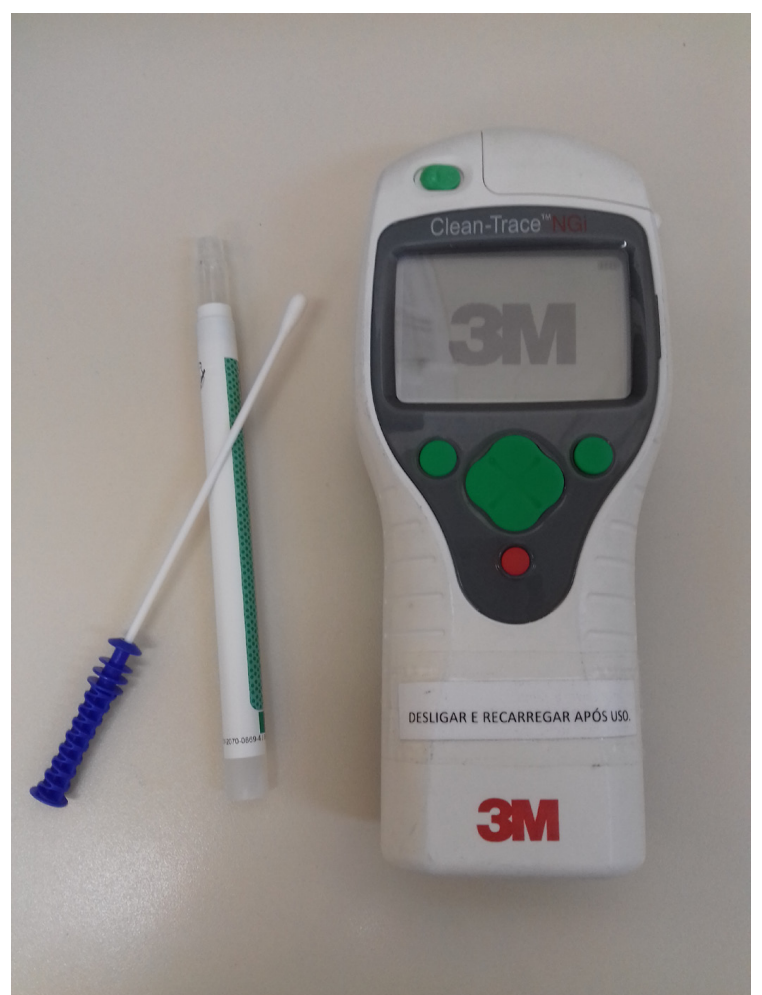

Figure 1: NGI Luminometer Clean-Trace ATPSurface Test, manufactured by 3M Health Care in St.Paul, Minnesota, USA and swabs in Wales, United Kingdom.

A value of $100 \mathrm{RLU}$ was used as the cutoff point according to the parameters of the Hospital Infection Control Committee $(\mathrm{CClH})$ to consider a clean surface.

\section{RESULTS}

The study included 105 health professionals. The mean ATP count, considering all material analyzed, was $1,673.20$ RLU. Among the materials analyzed, $68.5 \%$ were mobile phones and tablets. The mean ATP count was 2,257.7RLU for mobile phones, 1,572.80 RLU for stethoscopes, 1,449.0 RLU for watches; $812 \mathrm{RLU}$ for cameras; 790 RLU for identification cards, 784 RLU for notebooks and 426 RLU tablets (figure 2).

Among the professionals evaluated, only nursing technicians presented a count lower than 10 times the specified cutoff point. Residents, students, trainees and practical laboratory workers showed mean count of 20 times the specified cutoff point.

\section{DISCUSSION}

These results reinforce concerns that tablets, handbooks, mobile phones, identification cards, watches, stethoscopes and cameras could act as a source of bacterial pathogens that could be transmitted to patients through contamination of hands after use. Cleanliness of hospital surfaces is internationally advocated as

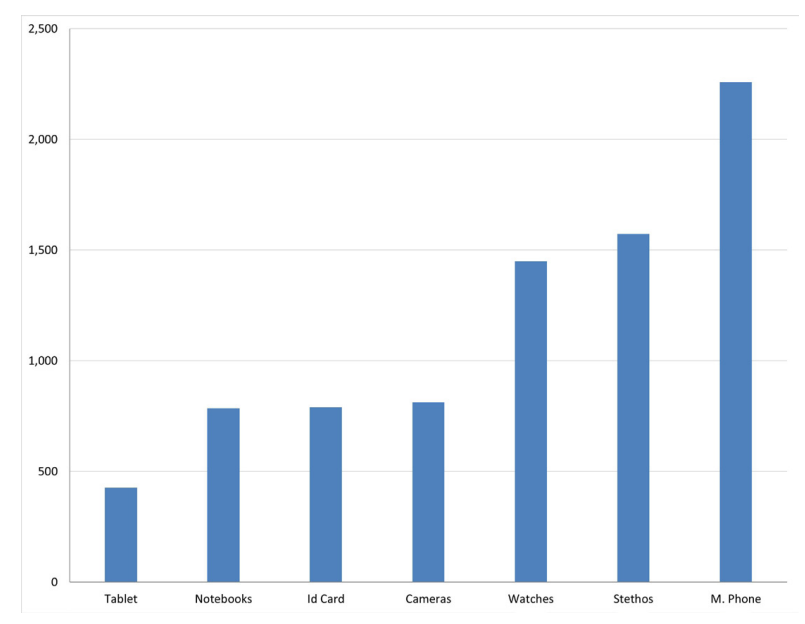

Figure 2: Dirty level of materials analyzed by clean trace, expressed in RLU.

necessary to control hospital infections, although there is still no consensus regarding the preferred methods for assessing cleanliness. The authors used ATP count to determine the presence of organic matter in some devices used by HCWs. ATP measurements were difficult to compare because there is no similar study and the parameters used were based on studies of cleanliness of hospital surfaces ${ }^{10}$.

The need to clean mobile phones is well known, and agents such as ethanol and isopropanol have been investigated for this purpose ${ }^{3}$.

More detailed research into mobile device infection control methods is expected to facilitate the development of guidelines. Precautions such as washing hands should be strictly followed to avoid the transmission and spread of infections (in particular nosocomial infections) due to mobile devices mainly. Recommendations in the literature include the use of nanotechnology, antibacterial coatings/covers, or silver metal to reduce the contamination rate of mobile phones ${ }^{3}$. These standards should be strictly implemented, especially in hospital settings. Due to the widespread use of touch-screen mobile devices, more comprehensive and detailed studies on disinfection methods are required to reduce infections that originate from their use ${ }^{3}$.

Considering the data presented, we see the importance of encouraging the cleaning of these materials, but especially hand hygiene of $\mathrm{HCW}$ following the use of these, respecting the five moments of hand hygiene as well as all the six steps. Campaigns may help professionals to become aware about their role in preventing infections ${ }^{11}$.

\section{Conflicts of interest}

The authors declare no conflicts of interest. 


\section{REFERENCES}

1. Pal S, Juyal D, Adekhandi S, Sharma M, Prakash R, Sharma $\mathrm{N}$, et al. Mobile phones: reservoirs for the transmission of nosocomial pathogens. Adv Biomed Res. 2015;4(1):144. PMid:26322292. http://dx.doi.org/10.4103/22779175.161553.

2. Hughes JM. Study on the efficacy of nosocomial infection control (SENIC Project): results and implications for the future. Chemotherapy. 1988;34(6):553-61. PMid:3243099. http://dx.doi.org/10.1159/000238624.

3. Koroglu M, Gunal S, Yildiz F, Savas M, Ozer A, Altindis M. Comparison of keypads and touch-screen mobile phones/devices as potential risk for microbial contamination. $J$ Infect Dev Ctries. 2015;9(12):130814. PMid:26719936. http://dx.doi. org/10.3855/jidc.6171.

4. Brady RR, Wasson A, Stirling I, McAllister C, Damani NN. Is your phone bugged? The incidence of bacteria known to cause nosocomial infection in healthcare workers' mobile phones. J Hosp Infect. 2006;62(1):1235. PMid:16099536. http://dx.doi. org/10.1016/j.jhin.2005.05.005.

5. Datta P, Rani H, Chander J, Gupta V. Bacterial contamination of mobile phones of health care workers. Indian J Med Microbiol. 2009;27(3):27981. PMid:19584520. http://dx.doi. org/10.4103/0255-0857.53222.

6. Chawla K, Mukhopadhayay C, Gurung B, Bhate P, Bairy I. Bacterial 'cell' phones: do cell phones carry potential pathogens? Online J Health Allied Sci. 2009;8:8.

7. Akinyemi KO, Atapu AD, Adetona OO, Coker AO. The potential role of mobile phones in the spread of bacterial infections. J Infect Dev Ctries. 2009;3(8):628-32. PMid:19801807. http://dx.doi.org/10.3855/jidc.556.

8. Ulger F, Esen S, Dilek A, Yanik K, Gunaydin M, Leblebicioglu H. Are we aware how contaminated our mobile phones with nosocomial pathogens? Ann Clin Microbiol Antimicrob. 2009;8(1):7. PMid:19267892. http:// dx.doi.org/10.1186/1476-0711-8-7.

9. Bhat SS, Hegde SK, Salian S. Potential of mobile phones to serve as a reservoir in spread of nosocomial pathogens. Online $J$ Health Allied Sci. 2011;10:14.

10. Amodio E, Dino C. Use of ATP bioluminescence for assessing the cleanliness of hospital surfaces: a review of the published literature (1990-2012). J Infect Public Health. 2014;7(2):92-8. PMid:24231159. http:// dx.doi.org/10.1016/j.jiph.2013.09.005.

11. Arias VA, Garcell HG, Ochoa YR, Arias KF, Miranda FR. Assessment of hand hygiene techniques using the World Health Organization's six steps. J Infect Public Health. 2016;9(3):3669. PMid:26707705. http://dx.doi. org/10.1016/j.jiph.2015.11.006.

Received: Oct 04, 2016 Accepted: Mar 28, 2017 